\title{
Effect of Weed Management Practices on Nutrient Uptake by Direct Seeded Upland Rice under Tripura Condition
}

\author{
M. Chakraborti*, B. Duary and M. Datta \\ ${ }^{1}$ Department of Agronomy, Krishi Vigyan Kendra (ICAR), West Tripura, India \\ ${ }^{2}$ Department of ASEPAN, Palli Siksha Bhavana, Visva-Bharati, Sriniketan, West Bengal, India \\ ${ }^{3}$ ICAR (RC) for NEH Region, Tripura Centre, Lembucherra and Principal, College of \\ Agriculture, Tripura, India \\ *Corresponding author
}

\begin{tabular}{|c|c|}
\hline & A B S T R A C T \\
\hline Keywords & \multirow{4}{*}{$\begin{array}{l}\text { Field experiment was conducted during the kharif season of } 2013 \text { and } 2014 \text { to study the } \\
\text { effect of weed management practices on nutrient uptake by direct seeded upland rice. The } \\
\text { experiment consisted of twelve treatments laid out in randomized complete block design } \\
\text { with three replication. The common weed flora found in the experimental field were } \\
\text { Amaranthus viridis, Oldenlendia corymbosa, Spilanthes acmella, Ludwigia parviflora, } \\
\text { Cleome rutidosperma, Malvestrum coromondalianeum among the broad leaf weed, } \\
\text { Digitaria sanguinalis among grasses and Cyperus iria among sedges. The highest uptake } \\
\text { of NPK was recorded by the treatment hand weeding thrice at } 15,30 \text { and } 45 \text { DAS, while } \\
\text { weedy check registered the lowest uptake values for all the major nutrients. Among the } \\
\text { other treatments, pendimethalin at } 1.0 \mathrm{~kg} \mathrm{ha}^{-1}+\text { one hand weeding at } 30 \text { DAS and } \\
\text { pendimethalin at } 1.0 \mathrm{~kg} \mathrm{ha}^{-1} \text { at } 2 \text { DAS }+ \text { bispyribac sodium at } 25 \mathrm{~g} \mathrm{ha}^{-1} \text { at } 20 \text { DAS were } \\
\text { found more efficient with respect to nutrient uptake. }\end{array}$} \\
\hline $\begin{array}{l}\text { Nutrient uptake, } \\
\text { Pendimethalin, } \\
\text { Hand weeding, } \\
\text { Direct seeded rice. }\end{array}$ & \\
\hline Article Info & \\
\hline $\begin{array}{l}\text { Accepted: } \\
\text { 04 October } 2017 \\
\text { Available Online: } \\
10 \text { December } 2017\end{array}$ & \\
\hline
\end{tabular}

\section{Introduction}

Rice is the source of subsistence for more than one third of human population, especially poor. It is the main staple food in the Asia and the Pacific region, providing almost $39 \%$ of calories (Yaduraju, 2013). Worldwide, 697.22 million tons of rice at an average yield of 4.4 tons $\mathrm{ha}^{-1}$ is being harvested from 158.43 million ha annually producing $21 \%$ of worlds food calorie supply. Almost $90 \%$ of the total rice is produced and consumed in Asia. Rice plays a pivotal role in Indian agriculture and is staple food for more than $60 \%$ of the population. In India it is a means of livelihood for millions of rural households. The practice of direct seeding of rice is gaining importance at present and year by year its area is increasing. Conventional puddled transplanted rice is a major source of greenhouse gas (GHG), particularly methane, causing global warming (Brye et al., 2013). Direct-seeded rice (DSR) is a feasible alternative to mitigate methane emission, besides saving water and labour. The DSR crop can save 3-4 irrigations compared to the transplanted rice without any yield penalty. Human labour use also reduced to $45 \%$ and tractor use to $58 \%$ in the DSR compared to transplanted rice. The yields are comparable 
with transplanted rice if crop is properly managed (Pathak et al., 2013). Weeds are a major constraint to rice production in directseeded systems as they increase production costs and cause yield losses. Hence, in order to achieve maximum return from the supplied inputs weed management at critical stages of crop weed competition is important. Hence the present investigation was carried out to study the effect of weed management practices.

\section{Materials and Methods}

A field experiment was conducted at Krishi Vigyan Kendra, South Tripura during the kharif (wet) season of 2013 and 2014 to study the influence of different weed management practices applied to direct seeded upland rice under Tripura condition. Twelve treatments viz. Pendimethalin at $1.0 \mathrm{~kg} \mathrm{ha}^{-1}$ at $2 \mathrm{DAS}$, Bispyribac sodium at $25 \mathrm{~g} \mathrm{ha}^{-1}$ at $25 \mathrm{DAS}$, Pendimethalin at $1.0 \mathrm{~kg} \mathrm{ha}^{-1}$ at $2 \mathrm{DAS}+$ one hand weeding at 30 DAS, Pendimethalin at $1.0 \mathrm{~kg} \mathrm{ha}^{-1}$ at $2 \mathrm{DAS}+$ bispyribac sodium at $25 \mathrm{~g} \mathrm{ha}^{-1}$ at 20 DAS, Metsulfuron methyl+ chlorimuron ethyl (Almix) at $4 \mathrm{~g}$ at 10 DAS followed by Bispyribac sodium at $25 \mathrm{~g}$ at 20 DAS, Pyrazosulfuron ethyl at $25 \mathrm{~g} \mathrm{ha}^{-1}$ at 3 DAS followed by bispyribac sodium at $25 \mathrm{~g}$ at 20 DAS, Fenoxaprop-p-ethyl at $60 \mathrm{~g} \mathrm{ha}^{-1}+$ metsulfuron methyl+ chlorimuron ethyl (Almix) at $4 \mathrm{~g} \mathrm{ha}^{-1}$ at $15 \mathrm{DAS}$, Stale seed bed + smother crop (cowpea) in between two rows of rice, Stale seed bed + one hand weeding at 30 DAS, Sesbania (broadcast) @ $25 \mathrm{~kg} \mathrm{ha}^{-1}$ during sowing of rice +2,4-D at $500 \mathrm{~g} \mathrm{ha}^{-1}$ at 25 DAS, Hand weeding at 15,30 and 45 DAS, Weedy check were assigned in a randomized block design replicated thrice. Rice variety NDR-97 was used for the experimental purpose with recommended package of practices.

The upland rice was fertilized as per package of practices recommended. Five tonnes of
Farm Yard Manure were applied at the time of field preparation for both the crop. Chemical fertilizers were applied to meet 60 $\mathrm{kg}$ nitrogen in the form of urea, $40 \mathrm{~kg}$ phosphorus in the form of single superphosphate and $40 \mathrm{~kg}$ potassium in the form of muriate of potash in the rice.

Weed counts at different stages $(15,30,60$ and at harvest stage) was taken by placing quadrat at random three sites in each plot and calculating the average. Weed sample from any of the quadrat was taken, grouped into grasses, broad leaved weed and sedges, dried and weighed. Weed dry matter was expressed category wise in $\mathrm{g} \mathrm{m}^{-2}$. Data on yield attributes, grain yield, straw yield, plant dry matter and nutrient $(\mathrm{N}, \mathrm{P}, \mathrm{K})$ content of rice were taken. Economics of different weed management practices was also studied. The data generated from the experiment were subject to analysis of variance (ANOVA) as applied to randomized block design describe by Cochran and Cox (1965).

\section{Results and Discussion}

\section{Effect on weed}

The experimental field was heavily infested with mixed flora of grassy, broad leaved and sedges. Predomonant weeds in the experimental field were Amaranthus viridis, Oldenlendia corymbosa, Spilanthes acmella, Ludwigia parviflora, Cleome rutidosperma, Malvestrum coromondalianeum among the broad leaf weed, Digitaria sanguinalis among grasses and Cyperus iria among sedges. All the treatments resulted in significant reduction in weed density and dry weight of weeds over weedy check during both the years (Table 1). Hand weeding thrice at 15, 30 and 45 DAS resulted in the lowest weed density, dry weight of weeds and highest weed control efficiency followed by pendimethalin at 1.0 $\mathrm{kg} \mathrm{ha}^{-1}$ at $2 \mathrm{DAS}+$ one hand weeding at 30 
DAS and pendimethalin at $1.0 \mathrm{~kg} \mathrm{ha}^{-1}$ at 2 DAS + bispyribac sodium at $25 \mathrm{~g} \mathrm{ha}^{-1}$ at 20 DAS. The highest weed density, weed dry weight and lowest weed control efficiency was observed with weedy check plot. There was no remarkable change in the weed density, dry weight and weed control efficiency between two years. Unchecked weed growth exploited the available nutrients and water, resulting in better growth and dry matter production. Similar observation have been made by Sunil et.al (2010) who reported that un weeded check recorded significantly higher weed population and weed dry weight.

Table.1 Effect of weed management practices on weed density, weed dry weight and weed control efficiency at 60 DAS

\begin{tabular}{|c|c|c|c|c|c|c|}
\hline \multirow[t]{2}{*}{ Treatments } & \multicolumn{2}{|c|}{$\begin{array}{l}\text { Weed density } \\
\left(\text { (no.m }^{-2}\right)\end{array}$} & \multicolumn{2}{|c|}{$\begin{array}{l}\text { Weed dry weight } \\
\left(\mathrm{g} \mathrm{m}^{-2}\right)\end{array}$} & \multicolumn{2}{|c|}{$\begin{array}{r}\text { Weed control } \\
\text { efficiency }(\%)\end{array}$} \\
\hline & 2013 & 2014 & 2013 & 2014 & 2013 & 2014 \\
\hline Pendimethalin at $1.0 \mathrm{~kg} / \mathrm{ha}$ at $2 \mathrm{DAS}$ & 60.00 & 56.00 & 145.57 & 134.61 & 42.14 & 46.14 \\
\hline $\begin{array}{l}\text { Bispyribac sodium at } 25 \mathrm{~g} / \mathrm{ha} \text { at } 25 \\
\text { DAS }\end{array}$ & 57.33 & 52.33 & 148.67 & 140.28 & 40.90 & 43.87 \\
\hline $\begin{array}{l}\text { Pendimethalin at } 1.0 \mathrm{~kg} / \mathrm{ha} \text { at } 2 \\
\text { DAS+ one hand weeding at } 30 \text { DAS }\end{array}$ & 32.33 & 27.67 & 61.33 & 50.10 & 75.62 & 79.95 \\
\hline $\begin{array}{l}\text { Pendimethalin at } 1.0 \mathrm{~kg} / \mathrm{ha} \text { at } 2 \mathrm{DAS} \\
+ \text { bispyribac sodium at } 25 \mathrm{~g} / \mathrm{ha} \text { at } 20 \\
\text { DAS }\end{array}$ & 33.67 & 31.33 & 65.44 & 51.82 & 73.99 & 79.27 \\
\hline $\begin{array}{l}\text { Metsulfuron methyl+ chlorimuron } \\
\text { ethyl (Almix) at } 4 \mathrm{~g} \text { at } 10 \text { DAS } \\
\text { followed by bispyribac sodium at } 25 \\
\mathrm{~g} \text { at } 20 \text { DAS }\end{array}$ & 55.33 & 50.33 & 141.03 & 132.55 & 43.94 & 46.97 \\
\hline $\begin{array}{l}\text { Pyrazosulfuron ethyl at } 25 \mathrm{~g} / \mathrm{ha} \text { at } 3 \\
\text { DAS followed by bispyribac sodium } \\
\text { at } 25 \mathrm{~g} \text { at } 20 \text { DAS }\end{array}$ & 49.00 & 43.67 & 132.87 & 122.67 & 47.18 & 50.92 \\
\hline $\begin{array}{l}\text { Fenoxaprop-p-ethyl at } 60 \mathrm{~g} / \mathrm{ha}+ \\
\text { metsulfuron methyl+ chlorimuron } \\
\text { ethyl (Almix) at } 4 \mathrm{~g} / \mathrm{ha} \text { at } 15 \text { DAS }\end{array}$ & 55.67 & 49.67 & 139.08 & 128.07 & 44.71 & 48.76 \\
\hline $\begin{array}{l}\text { Stale seed bed }+ \text { smother crop } \\
\text { (cowpea) in between two rows of } \\
\text { rice }\end{array}$ & 78.33 & 73.00 & 188.00 & 176.17 & 25.27 & 29.51 \\
\hline $\begin{array}{l}\text { Stale seed bed + one hand weeding } \\
\text { at } 30 \text { DAS }\end{array}$ & 66.00 & 61.00 & 158.60 & 147.60 & 36.95 & 40.94 \\
\hline $\begin{array}{l}\text { Sesbania (broadcast) @ } 25 \mathrm{~kg} / \mathrm{ha} \\
\text { during sowing of rice }+2,4-\mathrm{D} \text { at } 500 \\
\mathrm{~g} / \mathrm{ha} \text { at } 25 \text { DAS }\end{array}$ & 77.00 & 71.33 & 180.08 & 170.05 & 28.42 & 31.96 \\
\hline Hand weeding at 15,30 and 45 DAS & 19.33 & 17.33 & 49.02 & 38.59 & 80.52 & 84.56 \\
\hline Weedy check & $\begin{array}{c}112.3 \\
3\end{array}$ & 107.33 & 251.57 & 241.44 & 0.00 & 0.00 \\
\hline S. Em ( $( \pm)$ & 1.41 & 1.41 & 2.82 & 3.05 & - & - \\
\hline $\mathrm{CD}(\mathrm{P}=0.05)$ & 4.14 & 4.14 & 8.26 & 8.96 & - & - \\
\hline CV (\%) & 4.22 & 4.58 & 3.53 & 4.14 & & - \\
\hline
\end{tabular}


Table.2 Effect of weed control measures on yield performance and economics of direct seeded rice

\begin{tabular}{|c|c|c|c|c|c|c|c|c|}
\hline \multirow[t]{2}{*}{ Treatment } & \multicolumn{2}{|c|}{$\begin{array}{l}\text { Grain yield } \\
\qquad\left(\mathrm{t} \mathrm{ha}^{-1}\right)\end{array}$} & \multicolumn{2}{|c|}{$\begin{array}{l}\text { Straw yield } \\
\left(\mathrm{t} \mathrm{ha}^{-1}\right)\end{array}$} & \multicolumn{2}{|c|}{$\begin{array}{c}\text { Net return } \\
\left(\text { Rs. ha }{ }^{-1}\right)\end{array}$} & \multicolumn{2}{|c|}{$\begin{array}{l}\text { Return per } \\
\text { Rupee } \\
\text { invested }\end{array}$} \\
\hline & 2013 & 2014 & 2013 & 2014 & 2013 & 2014 & 2013 & 2014 \\
\hline $\begin{array}{l}\text { Pendimethalin at } 1.0 \mathrm{~kg} / \mathrm{ha} \text { at } \\
2 \mathrm{DAS}\end{array}$ & 2.15 & 2.36 & 3.89 & 4.21 & 14297 & 1.55 & 1.55 & 1.70 \\
\hline $\begin{array}{l}\text { Bispyribac sodium at } 25 \mathrm{~g} / \mathrm{ha} \\
\text { at } 25 \text { DAS }\end{array}$ & 2.21 & 2.26 & 3.65 & 4.22 & 11830 & 1.49 & 1.49 & 1.54 \\
\hline $\begin{array}{l}\text { Pendimethalin at } 1.0 \mathrm{~kg} / \mathrm{ha} \text { at } \\
2 \mathrm{DAS}+\text { one hand weeding at } \\
30 \mathrm{DAS}\end{array}$ & 3.30 & 3.59 & 5.03 & 5.28 & 25573 & 1.81 & 1.81 & 1.96 \\
\hline $\begin{array}{l}\text { Pendimethalin at } 1.0 \mathrm{~kg} / \mathrm{ha} \text { at } \\
2 \mathrm{DAS}+\text { bispyribac sodium at } \\
25 \mathrm{~g} / \mathrm{ha} \text { at } 20 \mathrm{DAS}\end{array}$ & 3.26 & 3.41 & 4.87 & 5.17 & 26010 & 2.02 & 2.02 & 2.11 \\
\hline $\begin{array}{l}\text { Metsulfuron methyl+ } \\
\text { chlorimuron ethyl (Almix) at } \\
4 \mathrm{~g} \text { at } 10 \mathrm{DAS} \text { followed by } \\
\text { bispyribac sodium at } 25 \mathrm{~g} \text { at } \\
20 \text { DAS }\end{array}$ & 2.49 & 2.65 & 3.72 & 4.65 & 16542 & 1.60 & 1.60 & 1.73 \\
\hline $\begin{array}{l}\text { Pyrazosulfuron ethyl at } 25 \\
\mathrm{~g} / \mathrm{ha} \text { at } 3 \text { DAS followed by } \\
\text { bispyribac sodium at } 25 \mathrm{~g} \text { at } \\
20 \text { DAS }\end{array}$ & 2.71 & 2.80 & 4.04 & 4.81 & 18490 & 1.73 & 1.73 & 1.82 \\
\hline $\begin{array}{l}\text { Fenoxaprop-p-ethyl at } 60 \mathrm{~g} / \mathrm{ha} \\
+ \text { metsulfuron methyl+ } \\
\text { chlorimuron ethyl (Almix) at } \\
4 \mathrm{~g} / \mathrm{ha} \text { at } 15 \text { DAS }\end{array}$ & 1.89 & 1.98 & 3.82 & 3.98 & 9188 & 1.39 & 1.39 & 1.45 \\
\hline $\begin{array}{l}\text { Stale seed bed }+ \text { smother crop } \\
\text { (cowpea) in between two rows } \\
\text { of rice }\end{array}$ & 1.86 & 2.01 & 3.79 & 4.01 & 6613 & 1.19 & 1.19 & 1.28 \\
\hline $\begin{array}{l}\text { Stale seed bed }+ \text { one hand } \\
\text { weeding at } 30 \text { DAS }\end{array}$ & 1.86 & 2.10 & 3.71 & 3.89 & 5203 & 1.07 & 1.07 & 1.20 \\
\hline $\begin{array}{l}\text { Sesbania (broadcast) @ } 25 \\
\mathrm{~kg} / \mathrm{ha} \text { during sowing of rice + } \\
2,4-\mathrm{D} \text { at } 500 \mathrm{~g} / \mathrm{ha} \text { at } 25 \mathrm{DAS}\end{array}$ & 1.81 & 1.93 & 3.75 & 3.74 & 9083 & 1.38 & 1.38 & 1.46 \\
\hline $\begin{array}{l}\text { Hand weeding at } 15,30 \text { and } \\
45 \text { DAS }\end{array}$ & 3.45 & 3.60 & 5.16 & 5.43 & 19713 & 1.54 & 1.54 & 1.61 \\
\hline Weedy check & 0.58 & 0.74 & 2.90 & 2.80 & -3450 & 0.66 & 0.66 & 0.78 \\
\hline S. Em $( \pm)$ & 0.11 & 0.13 & 0.22 & 0.17 & 1783 & 0.07 & 0.07 & 0.08 \\
\hline $\mathrm{CD}(\mathrm{P}=0.05)$ & 0.34 & 0.37 & 0.64 & 0.49 & 5230 & 0.22 & 0.22 & 0.23 \\
\hline CV (\%) & 8.62 & 8.93 & 9.40 & 6.70 & 23.29 & 8.39 & 8.39 & 8.95 \\
\hline
\end{tabular}


Table.3 Effect of weed management practices on nutrient uptake by direct seeded rice

\begin{tabular}{|l|c|c|c|c|c|c|}
\hline \multirow{2}{*}{ Treatment } & \multicolumn{2}{|c|}{$\begin{array}{c}\text { N uptake } \\
\left(\mathrm{kg} \mathrm{ha}^{-1}\right)\end{array}$} & \multicolumn{2}{c|}{$\begin{array}{c}\text { P uptake } \\
\left(\mathrm{kg} \mathrm{h}^{-1}\right)\end{array}$} & \multicolumn{2}{c|}{$\begin{array}{c}\text { K uptake } \\
\left(\mathrm{kg} \mathrm{ha}^{-1}\right)\end{array}$} \\
\cline { 2 - 7 } & $\mathbf{2 0 1 3}$ & $\mathbf{2 0 1 4}$ & $\mathbf{2 0 1 3}$ & $\mathbf{2 0 1 4}$ & $\mathbf{2 0 1 3}$ & $\mathbf{2 0 1 4}$ \\
\hline Pendimethalin at 1.0 kg/ha at 2 DAS & 61.85 & 66.97 & 8.90 & 9.64 & 71.69 & 82.10 \\
\hline $\begin{array}{l}\text { Bispyribac sodium at 25 g/ha at 25 } \\
\text { DAS }\end{array}$ & 60.78 & 65.74 & 8.77 & 9.15 & 69.28 & 79.18 \\
\hline $\begin{array}{l}\text { Pendimethalin at 1.0 kg/ha at 2 DAS+ } \\
\text { one hand weeding at 30 DAS }\end{array}$ & 87.40 & 94.52 & 13.02 & 13.52 & 96.94 & 99.95 \\
\hline $\begin{array}{l}\text { Pendimethalin at 1.0 kg/ha at 2 DAS + } \\
\text { bispyribac sodium at 25 g/ha at 20 } \\
\text { DAS }\end{array}$ & & & & & & \\
\hline $\begin{array}{l}\text { Metsulfuron methyl+ chlorimuron } \\
\text { ethyl (Almix) at 4 g at 10 DAS } \\
\text { followed by bispyribac sodium at 25 g } \\
\text { at 20 DAS }\end{array}$ & 66.05 & 90.19 & 12.46 & 12.86 & 93.42 & 100.99 \\
\hline $\begin{array}{l}\text { Pyrazosulfuron ethyl at 25 g/ha at 3 } \\
\text { DAS followed by bispyribac sodium at } \\
\text { 25 g at 20 DAS }\end{array}$ & 70.83 & 74.65 & 9.53 & 10.67 & 71.42 & 87.69 \\
\hline $\begin{array}{l}\text { Fenoxaprop-p-ethyl at 60 g/ha + } \\
\text { metsulfuron methyl+ chlorimuron } \\
\text { ethyl (Almix) at 4 g/ha at 15 DAS }\end{array}$ & 58.18 & 59.56 & 8.91 & 8.86 & 71.06 & 75.22 \\
\hline $\begin{array}{l}\text { Stale seed bed + smother crop } \\
\text { (cowpea) in between two rows of rice }\end{array}$ & 57.91 & 59.91 & 8.52 & 8.82 & 70.60 & 74.68 \\
\hline $\begin{array}{l}\text { Stale seed bed + one hand weeding at } \\
\text { 30 DAS }\end{array}$ & 56.37 & 61.05 & 8.05 & 8.49 & 68.96 & 73.01 \\
\hline $\begin{array}{l}\text { Sesbania (broadcast) @ 25 kg/ha } \\
\text { during sowing of rice + 2,4-D at 500 } \\
\text { g/ha at 25 DAS }\end{array}$ & 55.93 & 57.37 & 8.12 & 8.42 & 71.04 & 69.96 \\
\hline Hand weeding at 15, 30 and 45 DAS & 90.57 & 95.29 & 13.43 & 13.91 & 100.66 & 105.86 \\
\hline Weedy check & 32.17 & 32.61 & 4.96 & 4.81 & 51.06 & 50.10 \\
\hline & 2.87 & 3.04 & 0.61 & 0.52 & 4.03 & 3.55 \\
\hline & 8.43 & 8.91 & 1.79 & 1.54 & 11.80 & 10.42 \\
\hline & 7.62 & 7.55 & 11.09 & 9.05 & 9.16 & 7.45 \\
\hline
\end{tabular}

\section{Effect on the performance of rice crops}

Grain yield, straw yield, net return and return per rupee invested were highly influenced by different weed management practices. Among the different treatments, hand weeding thrice at 15,30 and 45 DAS recorded the highest grain and straw yield and this treatment was at par with pendimethalin at $1.0 \mathrm{~kg} \mathrm{ha}^{-1}$ at 2 DAS+ one hand weeding at 30 DAS and pendimethalin at $1.0 \mathrm{~kg} \mathrm{ha}^{-1}$ at $2 \mathrm{DAS}+$ bispyribac sodium at $25 \mathrm{~g} \mathrm{ha}^{-1}$ at 20 DAS during both the season (Table 2).

Effective and timely weed management under these treatments reduced the dry weight of weeds which facilitated the crop to have sufficient space, light, nutrient and moisture and ultimately results in increased grain and straw yield. 
Pendimethalin at $1.0 \mathrm{~kg} \mathrm{ha}^{-1}$ at $2 \mathrm{DAS}+$ bispyribac sodium at $25 \mathrm{~g} \mathrm{ha}^{-1}$ at 20 DAS recorded the highest net return (Rs. 23847/- in the first year and Rs. 26010/- in the second year) and return per rupee invested (2.02 and 2.11 ) in both the years and was found to be the most remunerative weed management practices. The herbicide pendimethalin at 1.0 $\mathrm{kg} \mathrm{ha}{ }^{-1}+$ one hand weeding at 30 DAS registered net return of Rs. 21427/- and 25573/- in the first year and second year respectively and was the next best treatment. This is simply due to higher grain and straw yield of the crop obtained from these treatments. Similar result was reported by Yakadri et al., (2016). Though the rice yield and gross return were the highest under hand weeding at 15,30 and $45 \mathrm{DAS}$, the data on net income and return per rupee invested showed that it was less remunerative than pendimethalin at $1.0 \mathrm{~kg} \mathrm{ha}^{-1}$ at $2 \mathrm{DAS}+$ bispyribac sodium at $25 \mathrm{~g} \mathrm{ha}^{-1}$ at 20 DAS and pendimethalin at $1.0 \mathrm{~kg} \mathrm{ha}^{-1}+$ one manual weeding at 30 DAS which implied that it was uneconomic and unnecessary to give three hand weeding during the entire crop growth.The net income was found negative under weedy check due to greater competition between rice and weed which led to poor growth of the crop, lower grain and straw yield. This is in conformity with the study conducted by Prashanth et al., (2016) who reported that the lowest net returns and $\mathrm{B}$ : C ratio was obtained in unweeded check in transplanted rice.

\section{Nutrient uptake by rice crop}

All weed control treatments recorded significant increase in $\mathrm{N}, \mathrm{P}$ and $\mathrm{K}$ uptake by the crops (Table 3). The highest uptake of NPK was recorded by the hand weeding at 15 , 30 and 45 DAS treatment, while weedy check registered the lowest uptake values for all the major nutrients. This was in congruity with the result of Mandal et al., (2011). Among the other treatments, pendimethalin at $1.0 \mathrm{~kg} \mathrm{ha}^{-1}$ + one hand weeding at 30 DAS and pendimethalin at $1.0 \mathrm{~kg} \mathrm{ha}^{-1}$ at $2 \mathrm{DAS}+$ bispyribac sodium at $25 \mathrm{~g} \mathrm{ha}^{-1}$ at 20 DAS were found more efficient with respect to nutrient uptake by direct seeded rice. The enhanced growth characters in these treatments contributed to high dry matter production and nutrient uptake being a product of dry matter production and nutrient content, it was enhanced under such situations. Gupta et al., (2015) reported that all weed control treatments recorded significant increase in $\mathrm{N}, \mathrm{P}$ and $\mathrm{K}$ uptake by the crop compared to weedy check. They also reported that the highest nutrient uptake was obtained in weed free treatment followed by pre-emergence herbicide integrated with one hand weeding or another herbicide.

It was evident that with minimum weeds to compete with, and share resources, the uptake of nutrients by the crop was facilitated, resulting in more vigorous crop growth and better yield under such treatments. Higher nutrient uptake of crop in these treatments was mainly attributed to lower weed population and weed dry weight and this helped the crop to grow well and absorb more nutrients from the soil. These results are in line with Sunil et al., (2011).

\section{References}

Brye, K. R., Rogers, C. W., Smartt, A. D. and Norman, R. J. 2013. Soil texture effects on methane emissions from directseeded, delayed-flood rice production in Arkansas. Soil Sci., 178(10): 519-529.

Cochran, W.G. and Cox, G.M. 1965. Experimental Design. John Willey and Sons, Inc. New York.

Gupta, V., Singh, S.P. and Yadav, R.S. 2015. Yield performance and nutrient uptake as influenced by integrated weed management in cluster bean. Indian $J$. 
of weed sci., 47(1):82-84.

Mandal, D., Kumar, R., Singh, D. and Kumar, P. 2011. Growth and yield of directseeded rice (Oryza sativa) as influenced by sowing dates and weed management methods. International Journal of Bio resource and Stress Management 2(3): 273-276.

Pathak, H., Sankhyan, S., Dubey, D. S., Bhatia, A. and Jain, N. 2013. Dry direct-seeding of rice for mitigating greenhouse gas emission: field experimentation and simulation. Paddy and Water Environment, 11(1/4): 593601.

Prashanth, R., Kalyana Murthy, K.N., Madhu Kumar, V., Murali, M. and Sunil, C.M. 2016. Bispyribac-sodium influence on nutrient uptake by weeds and transplanted rice. Indian J. of Weed Sci., 48(2): 217-219.

Sunil, C.M., Shekara, B.G., Ashoka, P., Kalyanamurthy, K.N. and
Madhukumar, V. 2011. Effect of integrated weed management practices on nutrient uptake in aerobic rice (Oryza sativa L.), Research on Crops, 12(3): 629-632.

Sunil, C.M., Shekara, B.G., Kalyanamurthy, K.N. and Shankaralingappa, B.C., 2010. Growth and yield of aerobic rice as influenced by integrated weed management practices. Ind. J. Weed Sci.37:40-44.

Yaduraju, N. T. and Rao, A. N. 2013. Implications of weeds and weed management on food security and safety in the Asia-Pacific region. Proc. 24th Asian-Pacific Weed Science Society Conference.22-25 October, 2013, Bandung, Indonesia, pp 13-30.

Yakadri, M., Madhavi, M., Ramprakash, T. and Leela, R. 2016. Herbicide combinations for control of complex weed flora in transplanted rice. Indian J. of Weed Sci., 48(2): 155-157.

\section{How to cite this article:}

Chakraborti, M., B. Duary and Datta, M. 2017. Effect of Weed Management Practices on Nutrient Uptake by Direct Seeded Upland Rice under Tripura Condition. Int.J.Curr.Microbiol.App.Sci. 6(12): 66-72. doi: https://doi.org/10.20546/ijcmas.2017.612.008 